\title{
Sustainable Development Indicators in Kazakhstan: Problems of Theory, Methodology and Practice
}

\author{
OrynkanovaZhanar \\ L.N. Gumilyov Eurasian National University \\ Kazakhstan \\ Prof. Sung-Kyu Lee \\ Department of International Trade \\ Andong National University \\ Korea
}

\begin{abstract}
To assess the progress of civilization as a whole, the region, the country and its administrative units to sustainability or, conversely, its loss need quantitative characteristics, specially constructed indicators, which called indicators of sustainable development. These indicators are important not in themselves, but as a tool for achieving sustainable development goals and correcting this development. It is too early to talk about the completeness of the set of indicators of sustainable development, nor about the sufficient accuracy of their calculation. The article deals with theoretical, methodological and practical aspects of measuring sustainable development. Based on the analysis, four approaches to indicators of sustainable development are used. International ratings and indicators of sustainable development reflecting the situation of Kazakhstan are considered. Kazakhstan is significantly behind the developed countries in most indicators, especially in indicators that reveal the ecological state of the country. The analysis of Kazakhstan's position in the international rankings revealed a number of methodological factors that affect its position and at the same time not always provide an objective description of the environmental situation. Based on the assessment, we summarized the strengths and weaknesses of the environmental development in Kazakhstan.
\end{abstract}

Keywords: Sustainable development, Indicators of sustainable development, Environmental policy, Integral indicator.

JEL Classifications: O13, O15, O21, Q01.

\section{Introduction}

How to assess the level of development of the country? Why is GDP not an adequate measure of a country's welfare? This is now one of the central problems of economic science, as well as governments and companies. In this regard, of great interest is the book by Stiglitz, Sen and Fitoussi,Mis-measuring Our Lives: Why GDP Doesnot Add Up, where the authors comprehensively consider the shortcomings of GDP as an indicator of the well-being of society, focusing on the fact that GDP does not take into account economic inequality and the environmental consequences of economic decisions ${ }^{1}$. At the same time, many countries use this indicator as a universal measure of the success of the state, including Kazakhstan.

In the early 2000s, Kazakhstan's GDP growth reached $13.5 \%$ : in other words, the country's economy is growing and society is waiting for a better life. However, this growth is mainly due to the rapid increase in exports of oil and minerals, and oil prices: the price of oil increased from $\$ 40$ per barrel to $\$ 140$. The fall in oil prices revealed the illusion of false development, and the decline in oil prices is result in a decrease in GDP growth. Thus, it becomes obvious that we need to look for other indicators of development, since GDP, in this respect, is not the best indicator. Bobylev in his interview gives an example: "GDP and the bike. The cyclist is a very harmful person for GDP growth: he does not buy a car, does not repair it, does not insure it, and does not get into an accident; the cyclist is healthy, rarely goes to doctors, buys little medicine, and all this reduces costs and everything that goes into GDP. Thus, GDP creates a false picture of development." At the same time, it is impossible to abandon GDP completely, as it focused on short-term results and economic growth, but it does not take into account social and environmental problems.

\footnotetext{
${ }^{1}$ Stiglitz, J.E., A. Sen and J.P. Fitoussi (2010), Mis-measuring Our Lives: Why GDP Does not Add Up, The New Press.

${ }^{2}$ Bobylev, S. (2017),Sustainable Development Indicator, https://postnauka.ru/video/80745 (in Russian).
} 
For example, BRICS is a group of five rapidly developing countries that has a third of the world's GDP. But how will GDP growth be achieved? In China, growth achieved at the expense of critical environmental problems, and the same picture appears in India and Brazil. In economic theory, a clear conclusion is reached so that GDP can grow, but this can occur due to the degradation of nature and the growth of social problems. GDP, for example, does not reflect health. It does not convey the gap, and in the world and Kazakhstan it is an acute problem - the gap between rich and poor. That is, GDP is growing, the poor are getting poorer, the rich are getting richer. When we talk about GDP growth in Kazakhstan, the golden era of GDP in the early 2000s, it should be noted that the country lived at the expense of depletion and degradation of natural capital. Kazakhstan extracted oil, gas and coal, cut wood, quickly sold it, and our GDP grew. But from the point of view of sustainable development, this is an absurd situation, because sustainable development is development in the interests of future generations. It is clear that the well-being of future generations is undermined by the depletion of natural capital. And so the question arises: how to measure all this? After all, if we measure something wrong, then we will do something wrong. How to assess the development of the economy and society? These questions are answered by a stormy, completely new branch of economic science related to indicators of sustainable development.

\section{Theoretical Aspects of Sustainable Development Indicators}

Indicators of sustainable development should reflect the economic, social and environmental aspects of meeting the needs of the present generation without limiting the needs of future generations to meet their own needs. For development to be considered sustainable, it must take into account the achievement of economic growth, but it must be balanced with the needs of society to improve the quality of life and to prevent environmental degradation. Indicators are designed to solve the following four tasks:

\begin{tabular}{|l|l|}
\hline \multicolumn{1}{|c|}{ Task } & \multicolumn{1}{c|}{ Contents } \\
\hline $\begin{array}{l}\text { (1) Definition of } \\
\text { objectives }\end{array}$ & $\begin{array}{l}\text { - identifying specific policy objectives for sustainable development in } \\
\text { quantitative form; } \\
\text { - developing strategies for future development; } \\
\text { - forecasting the impact of planned activities. }\end{array}$ \\
\hline $\begin{array}{l}\text { (2) Management } \\
\text { - } \text { - assessment of progress; } \\
\text { - assessing the effectiveness of previous policies; } \\
\text { - information for planning and decisionmaking by authorities; } \\
\text { - improving the quality of management decisions, taking into account the } \\
\text { positions and interests of different groups of the population. }\end{array}$ \\
\hline $\begin{array}{l}\text { (3) Assessment of the } \\
\text { situation in the country } \\
\text { and the world }\end{array}$ & $\begin{array}{l}\text { - interregional comparisons, justifications of transfers; } \\
\text {-relation of the region with the international community, attraction of } \\
\text { foreign investments, programs, grants. }\end{array}$ \\
\hline (4) Public participation & $\begin{array}{l}\text { - information, training, communication with society and individual } \\
\text { groups; } \\
\text {-involvement of the public in civic activities. }\end{array}$ \\
\hline
\end{tabular}

In the context of policy development and in connection with the above tasks, sustainable development indicators should perform the following four functions.

First, define or express objectives arising from national strategic programs. The indicators reflect the key objectives and activities identified in the country's socio-economic development programs. This will make it possible to set a number of targets for each indicator, thus providing a clearer vision and understanding of the overall policy objectives.

Second, provide a basis for assessing the implementation of these strategies at different levels (technical and management objectives). Indicators enable the measurement, monitoring, evaluation and analysis of the rate and efficiency of the movement towards the achievement of sustainable development and to adjust the overall policy and thus to steer development in the right direction, ensuring its stability. It also makes it possible to transfer responsibility for the achievement of certain individual targets to different agencies (e.g., health or employment indicators) and even to carry out (partial) evaluation of the effectiveness of certain elements of the governance structure in achieving certain policy objectives.

Third, indicators can also be used to inform planning and decision-making processes. It is advisable, first of all, to inform about the consequences and the results of implementation of special programs for sustainable development adopted in some departments and organizations, so that these impacts and outcomes could be analyzed in a broader context. 
For example, indicators can be used as a basis for assessing the long-term sustainability of socio-economic policies and programs, as well as for identifying additional opportunities for more active participation of individual organizations in sustainable development that are not so obvious as to be identified at the first review.

Finally, to inform the general public about the implementation of the strategies and the pace of progress towards sustainable development in a clear and accessible manner that can stimulate the necessary changes in the behavior of the population.

There are many approaches and methods for assessing the environmental status and sustainable development at different territorial levels. One of these tools is the numerous environmental ratings that can evaluate countries, regions, cities, companies and enterprises. Ratings represent research results in a form that is accessible not only to the scientific community, but also to the general public, so they are often cited in the media. Currently, global environmental ratings have become an important element in assessing the achievements of individual countries in the field of preserving a favorable environment, sustainable development, a movement towards a "green" economy, the implementation of responsible climate policy, and others ${ }^{3}$.

To overcome the paradox and absurdity of GDP, it is necessary to pay attention to indicatorsof sustainable development. The world now has several approaches to indicators of sustainable development. We can divide these approaches into 4 groups: (1) the integral indicator of sustainability, (2) a system of indicators or indicators of sustainable development, (3) specific indicators, particular indicators, and (4) sociological survey.We examined these approachesin more details in Table 1.

\section{Table 1. Classification of Approaches to Indicators of Sustainable Development}

\begin{tabular}{|c|c|c|c|}
\hline Approach & Name of indicators & Advantages & Disadvantage \\
\hline \multirow{6}{*}{ 冚 } & $\begin{array}{l}\text { Adjusted Net SavingsIndex }{ }^{4}(1993, \text { World Bank): Based on official } \\
\text { statistics, characterizes the rate of accumulation of national savings } \\
\text { after taking into account the depletion of natural resources and damage } \\
\text { from environmental pollution. It measured as a percentage of gross } \\
\text { national income. }\end{array}$ & \multirow{6}{*}{$\begin{array}{l}\text { 1. Convenient and easy to } \\
\text { understand. } \\
\text { 2. A huge number of } \\
\text { different indicators with } \\
\text { an emphasis on the } \\
\text { economy, society or } \\
\text { environment. } \\
\text { 3. Objectivity, as the } \\
\text { calculation is carried out } \\
\text { byindependent } \\
\text { organizations }\end{array}$} & \multirow{6}{*}{$\begin{array}{l}\text { 1. Geographicaldifferences of } \\
\text { countries, differences in } \\
\text { economic and social } \\
\text { development are not considered. } \\
\text { 2. Nogenerally accepted integral } \\
\text { indicator. } \\
\text { 3. Due to the need for complex } \\
\text { calculations, the data for } \\
\text { calculations are often outdated. }\end{array}$} \\
\hline & $\begin{array}{l}\text { Environment PerformanceIndex }{ }^{5}(2006 \text {, Yale University Center for } \\
\text { Environmental Policy and Law(USA): this index is calculated in two } \\
\text { large groups: environmental health (protection of human health against } \\
\text { environmental hazards caused by human activities) and ecosystem } \\
\text { viability (protection of ecosystems and use of resources). The } \\
\text { effectiveness of the environmental policy of the countries is assessed. } \\
\text { There are } 9 \text { categories of environmental problems and } 19 \text { indicators. }\end{array}$ & & \\
\hline & $\begin{array}{l}\text { Global Innovation Index }{ }^{6}(2007, \text { Cornell University(USA), INSEAD } \\
\text { International Business School(France) and WIPO): thisindex is } \\
\text { calculated by } 7 \text { groups of indicators. It shows the potential of } \\
\text { innovative activity of the states. }\end{array}$ & & \\
\hline & $\begin{array}{l}\text { Human Development Index }{ }^{7}(1990, \text { United Nations Development } \\
\text { Program): this index is calculated annually for cross-country } \\
\text { comparison and measurement of living standards, literacy, education } \\
\text { and longevity as the main characteristics of the human potential of the } \\
\text { study area. }\end{array}$ & & \\
\hline & $\begin{array}{l}\text { The Ecological Footprint }{ }^{8}(1992, \text { Global Footprint Network): an } \\
\text { indicator of human impact on the environment, which allows us to } \\
\text { calculate the size of the surrounding area necessary for the production } \\
\text { of environmental resources consumed by us and the absorption of } \\
\text { waste. On a global scale, the ecological footprint indicates how } \\
\text { quickly humanity consumes natural (natural) capital. Measured in } \\
\text { square kilometers. }\end{array}$ & & \\
\hline & $\begin{array}{l}\text { Sustainable Society Index }{ }^{9}(2006, \text { Foundation for Sustainable } \\
\text { Society(Netherlands)): this index is calculated in three areas - social, } \\
\text { environmental and economic well-being of } 21 \text { indicators. }\end{array}$ & & \\
\hline
\end{tabular}

\footnotetext{
3 Alekseeva, N.N., M.A. Arshinova, and A.I. Bancheva(2018), "Russia's Position in International Environmental Ratings",RUDN Journal of Ecology and Life Safety,26(1), pp.134 152 (doi10.22363/2313-2310-2018-26-1-134-152).

${ }^{4}$ The Little Green Data Book (2017), Washington, DC: World Bank. (doi: 10.1596/978-1-4648-0928-6), http://documents.worldbank.org. ${ }^{5} \mathrm{Hsu}$, A. et al. (2016),The 2016 Environmental Performance Index, New Haven, CT: Yale University(www.epi.yale.edu.)

${ }^{6}$ The Global Innovation Index 2018: Energizing the World with Innovation (2018), Cornell University, INSEAD, and the World Intellectual Property Organization, https://www.wipo.int/publications/ru/details.jsp?id=4330.

${ }^{7}$ Human Development Indices and Indicators (2018), United Nations Development Program, New York,www.undp.org.

${ }^{8}$ Global Footprint Network (2016), National Footprint Accounts, 2016 Edition, https://www.footprintnetwork.org.

${ }^{9}$ Sustainable Society Index (2016), Sustainable Society Foundation, http://www.ssfindex.com.
} 


\begin{tabular}{|c|c|c|c|}
\hline Approach & Name of indicators & Advantages & Disadvantage \\
\hline 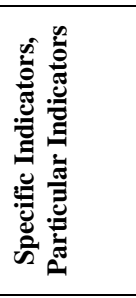 & $\begin{array}{l}\text { The indicator of energy efficiency and energy intensity shows the } \\
\text { amount of energy resources to obtain a unit of the final result. } \\
\text { Carbon footprint and carbon economy are the amount of greenhouse } \\
\text { gas emissions generated as a result of human activities. }\end{array}$ & $\begin{array}{l}\text { 1. Ease and convenience in } \\
\text { the perception of specific } \\
\text { information. } \\
\text { 2. The use of private } \\
\text { indicators in thematic } \\
\text { areas gives a much } \\
\text { clearer picture of the } \\
\text { situationwith stability } \\
\text { levels. }\end{array}$ & $\begin{array}{l}\text { 1. Narrow focus: to complete the } \\
\text { picture it is necessary to take } \\
\text { into account several specific } \\
\text { indicators. }\end{array}$ \\
\hline 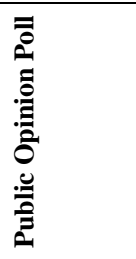 & $\begin{array}{l}\text { Questionnaires, surveys of the population on how satisfied they are } \\
\text { with the level of their lives, how satisfied they are with the state of the } \\
\text { environment, how satisfied they are with how the government solves } \\
\text { environmental problems. This is also an important indicator of the } \\
\text { state of society and development. It is very widely used now in the } \\
\text { world in various countries. }\end{array}$ & $\begin{array}{ll}\text { 1. } & \text { Study and } \\
\text { identification of } \\
\text { problems of } \\
\text { public concern. }\end{array}$ & 1. Subjectivity. \\
\hline
\end{tabular}

This table shows the following approaches, each of which has its advantages and disadvantages.

\section{(1) First approach}

Integrated indicators of sustainable development are actively developed by various public organizations (UN, World Bank, OECD, etc.) and universities.The multiplicity of existing approaches to the assessment of stability of development of economy leads to the conclusion that the universally accepted approach or measure did not yet exist. Individual countries are developing their own indicators to measure sustainability.

The main difficulty in compiling complex indices is the adequacy of the parameters for the presentation of interrelated components of environmental development (economy, social sphere, institutions, scientific and technological policy, environmental indicators and other aspects). A publication by German scientists ${ }^{10}$, analyzing sustainable development indices with the characteristic title of "Measurement of the immeasurable", refers to the need for a correlation between baseline indicators in the development of environmental indices. According to the authors, the selected sustainability indicators are currently used, often are misled when making decisions on environmental issues. Furthermore, the objectivity of the indices is complicated by the need to take into account the different geographical conditions and levels of socio-economic development of countries. That is why some international organizations, including the European Environment Agency ${ }^{11}$, prefer sets of individual indicators to the development of complex indices, which may be less reliable than their components. The aggregation of diverse indicators into a single index raises a number of "technical" issues addressed in the report of the UN Commission on Sustainable Development (Report on the Aggregation of Indicators for Sustainable Development, 2001). A key consideration when aggregating the information in the indices is the determination of the weights of the baseline without too much subjectivity and without losing their significance. The higher the level of information aggregation, the more difficult it is to weigh incomparable values. It is difficult to bring together different regions with different priorities and disparate problems. The best solution is the selection of weights that suit all regions. But reaching consensus is extremely difficult. As a solution, it is proposed that each region independently determine the weights of indicators on the basis of established priorities. However, it should be borne in mind that the results in this case are incomparable, and this makes it difficult to further analysis. A compromise solution is the use of differentiated weights for individual regions for internal analysis and the use of uniform weights for interregional comparisons ${ }^{12}$.

\footnotetext{
${ }^{10}$ Böringer, C. and P.Jochem (2007), “Measuring the Immeasurable: A Survey of Sustainability Indices”, ZEW Discussion Paper, No. 06073 .

${ }^{11}$ EEA Technical Report(2014),Digest of EEA Indicators 2014, European Environment Agency.

${ }^{12}$ Indicators of Sustainable Development of Russia: Ecological and Economic Aspects (2001) by S. N. Bobylev and P. A. Makeenko, Moscow(in Russian).
}

62 
The process of information aggregation is formalized as follows. At the first level, the weights of the indicators for the selected problems are determined in order to obtain an index for each problem. At the second level, intermediate indices are weighed and the index is determined by the selected areas. At the third level, the indices of the second level are weighed and a single index is determined.

It is possible to aggregate to the level of the main aspects of development like environmental, economic, social, institutional, and to obtain an index for each of these aspects. The ecological aspect unites air, land, oceans, seas, coasts, clean water, and biodiversity. The economic dimension combines economic structure, production and consumption. The social aspect combines health, education, equality, housing, security, and population. The institutional dimension includes the organization and capacity of institutions.

\section{(2) Second approach}

As part of this development-oriented approach system of sustainability indicators, there are various options for the structure of such a system:

(i) The structure of "subject/problem-indicator", when a specific issue has a corresponding indicator. There are usually three groups of indicators: economic, social and environmental.

(ii)Structure of "goals-objectives-indicators": hierarchical structure of the approach to indicator development. Goals and objectives can only be formulated and have, unlike indicators, no quantitative expression.

(iii) Compact system and key/basic indicators. Key indicators should be selected in such a way as to reflect the priority problems and specifics of the region, including the features of the current period of its development.

(iv) Structure of the "theme and sub-theme indicator".

(v) Differentiation of the structure of indicators into pressure-state-response indicators, which is characteristic of the Organization for Economic Cooperation and Development (OECD) systems) ${ }^{13}$.

One of the most comprehensive systems of sustainable development indicators was adopted in 2015. Sustainable Development Goals (SDGs), officially known as the Transformation of OurWorld: the 2030Agenda for Sustainable Development are a set of goals for future international cooperation that replaced the Millennium Development Goals at the end of 2015. These goals are planned to achieve from 2015 to 2030. The outcome document of "the Transformation of Our World: An Agenda for Sustainable Development for the Period till 2030" contains 17 goals and 169 of the respective tasks.

The OECD system of environmental indicators is also widely recognized in the world. They are divided into several types:

-Core set of OECD environmental indicators for assessing environmental performance.

-Several sets of sectoral indicators - to ensure the integration of environmental issues into sectoral policies.

-Indicators derived from environmental reporting - to ensure both the integration of environmental issues into sectoral policies and the sustainability of the use and management of natural resources.

It is expected that the OECD indicator system will provide an opportunity to clarify the links between the economy and environmental protection, thus increasing public awareness and promoting integrated policies. The OECD has developed a pressure-state-response model (JEM). Human activity exerts "pressure" on the environment and affects the quality and quantity of natural resources ("state"); society responds to these changes through environmental, general economic and sectoral policies and through changes in public consciousness and behavior ("pressure response"). The JEM model identifies causal links between economic activity and environmental and social conditions and helps decision makers and the public to see the linkages between these areas and to develop policies to address these issues. It is therefore a mechanism for selecting and organizing indicators in a form that is convenient for decision makers and the public. However, this does not mean ignoring the more complex relationships in ecosystems, as well as economic, environmental and socio-environmental linkages. "Pressure" includes indirect and direct pressure (i.e., use of resources and release of pollutants and waste). Environmental pressure indicators are closely related to the nature of production and consumption, and often reflect the intensity of emissions or use of resources, as well as trends and changes over time. They can be used to illustrate the process of breaking the link between economic activities and related environmental problems. They can also be used to assess the effectiveness of national objectives and international commitments (i.e., plans to reduce emissions). The ecological state is related to the quality of the environment and the quantity and quality of natural resources. As such, they reflect the ultimate goal of environmental policy.

\footnotetext{
${ }^{13}$ Bobylev, S. N. (2007), “Indicators of Sustainable Development: Regional Dimension”,Handbook ofRegional Environmental Policy, Moscow: Acropolis, CEPR (in Russian).
} 
Environmental indicators are designed to provide an overview of the environmental situation and its development over time. Examples are: (i) concentrations of pollutants in the environment,(ii) exceedance of critical loads, (iii)the impact of a certain level of pollution on the population or a decrease in the quality of the environment and related health effects, and (iv) the state of flora and fauna and natural resources. Response indicators reflect the extent to which society responds to environmental problems.

They involve collective and individual actions and reactions aimed at mitigating, adapting or preventing adverse environmental impacts caused by human activities or at preserving nature and natural resources. Examples of public response indicators are environmental costs, environmental taxes and subsidies, pricing structure, market share of environmentally friendly goods and services, rate of pollution reduction, and level of recycling.

The OECD JEM model formed the basis of many other indicator systems - in particular, the European Eurostat impact indicators. OECD environmental indicators are regularly used in related conservation activities and other analytical work; they can be used to monitor the integration process of making economic and environmental decisions, to analyze policy in the field of conservation and to assess conservation outcomes. They are also used in the broader OECD program on sustainable development indicators.

\section{(3) Third approach}

In recent years, the world is increasingly along with systems containing a lot of indicators, developed "compressed" system of indicators. A shortened list of so-called key (or basic) indicators of sustainable development reflecting important environmental issues is recommended for decision makers who need only the highest priority information on sustainable development and environmental protection. Along with aggregated indicators, environmental intensity indicators are widely used to assess the sustainability of regional and country policies, reflecting the cost of natural resources and the amount of pollution per unit of the final result. Indicators of energy intensity, environmental intensity and their types play an important role here. Material intensity is defined as the consumption of minerals and metals per unit of GDP. There includes consumption of primary and secondary materials, changes in inventories, and imports and exports of materials. The per capita consumption of materials is recommended as a supporting indicator for the analysis of material consumption trends. The indicator serves as an indirect characterization of industrial pollution and also reflects the level of economic development and the structure of the economy. Difficulties in calculating the indicator at the regional level are noted, as it is necessary to assess interregional flows of materials in semi-finished products. The indicator "per capita consumption of all types of energy" includes production, changes in stocks at the end of the year, imports minus exports. The indicator, on the one hand, is related to environmental indicators - climate change, air quality, land use, on the other hand, reflect economic and social aspects. The complexity of interpretation of this indicator is noted.

The importance of per capita energy consumption is largely determined by social, economic and geographical factors. More or less per capita energy consumption does not necessarily indicate greater or lesser sustainability. Therefore, this indicator should be complemented by other indicators of economic development and energy use. Renewable energy consumption as a share of total energy consumption reflects the dependence on exhaustible energy sources and is a good indicator of the country's sustainability. Renewable energy sources include hydro, geothermal, nuclear, solar, wind, tidal, bioenergy, industrial and municipal waste. Energy consumption is calculated as primary production plus changes in inventories, plus imports, minus exports.

By themselves, indicators of environmental capacity say little. Their main advantages are manifested in their measurement in dynamics or in comparison with other countries, economic structures, technologies, etc. Currently, the economy of Kazakhstan and its regions is extremely nature-intensive and requires much more specific consumption of natural resources (pollution) for production compared to the existing economic structures of other countries and modern technologies.

Private, specific indicators are very useful in informing the public about basic sustainability issues. This helps the public to understand what sustainability is and why it is important, as well as to assess the pace of the country's progress towards sustainable development. Experience shows that key indicators are often popular among the population when they reflect the issues that concern everyone. Their use to reflect sustainable development activities will increase public confidence in the authorities and promote public participation ${ }^{14}$.

\section{(4) Fourth approach}

The indicators of sustainable development obtained on the basis of sociological research are quite new for the world. Typical issues in this area include "satisfaction with environmental actions" on the part of the population. Sociological

\footnotetext{
${ }^{14}$ Bobylev, S. N. (2007), “Indicators of Sustainable Development: Regional Dimension”,Handbook ofRegional Environmental Policy, Moscow: Acropolis, CEPR(in Russian). 
survey is important for several reasons: firstly, it allows to obtain additional information about the level of sustainability in the country, and secondly, to collect additional information, ideas, opinions, alternative solutions to issues. Thus, all four approaches have their pros and cons. It seems logical that a universal approach to environmental assessment and sustainable development cannot be developed for all countries. To complete the picture, it is necessary to use different indicators.

\section{Kazakhstan's Position in International Environmental Ratings}

International environmental ratings in recent decades have become an important tool for assessing the progress of countries in the implementation of environmental policies and sustainable development goals. To assess the sustainable development of Kazakhstan, we will present its results on the most representative ratings. And also compare Kazakhstan with the developed countries of the world.

A wide range of sustainability indicators characterizing international comparisons in the area of efficiency of natural resource potential use and environmental impact are presented in Table 2, compiled by country on the basis of data from various ratings and the World Bank. The selected comparison of indicators of the CIS countries, developed countries and BRICS is given.

\section{Table 2.Indicators of Sustainable Development in Selected Countries}

\begin{tabular}{|c|c|c|c|c|c|c|c|c|c|c|c|c|c|c|c|}
\hline \multirow{2}{*}{ Countries } & \multirow[b]{2}{*}{ 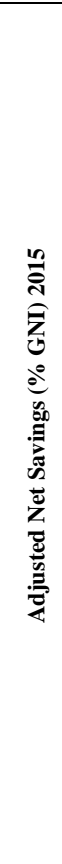 } & \multirow[b]{2}{*}{ 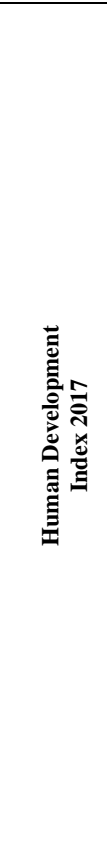 } & \multirow[b]{2}{*}{ 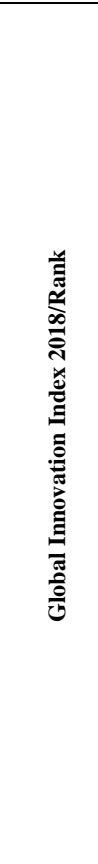 } & \multicolumn{3}{|c|}{$\begin{array}{c}\text { Sustainable } \\
\text { Society Index } \\
\text { Ranking } 2016 \\
\end{array}$} & \multirow[b]{2}{*}{ 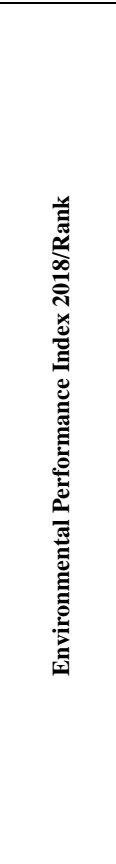 } & \multirow[b]{2}{*}{ 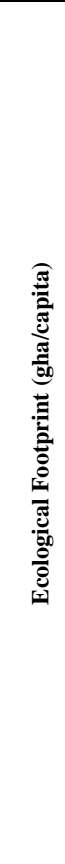 } & \multirow[b]{2}{*}{ 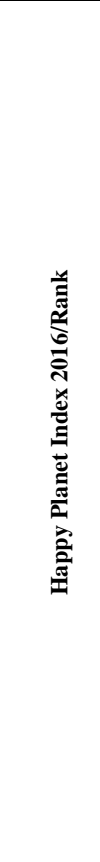 } & \multirow[b]{2}{*}{ 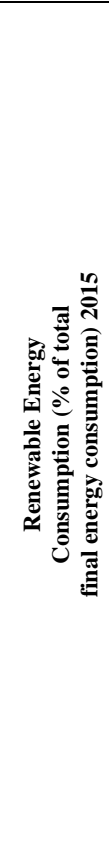 } & \multirow[b]{2}{*}{ 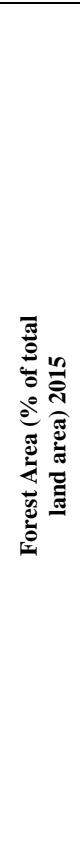 } & \multirow[b]{2}{*}{ 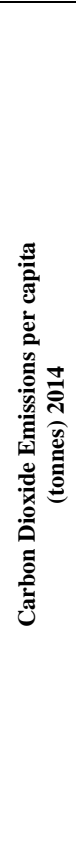 } & \multirow[b]{2}{*}{ 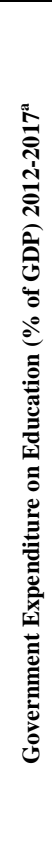 } & \multirow{2}{*}{ 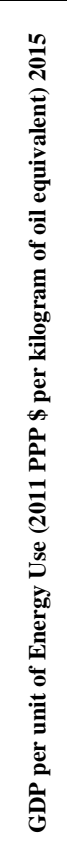 } & \multirow{2}{*}{ } \\
\hline & & & & 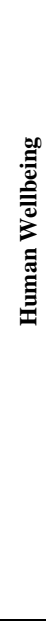 & 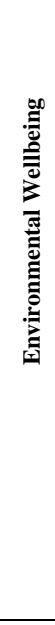 & 苛 & & & & & & & & & \\
\hline Norway & 20.6 & $0.953 / 1$ & $52.63 / 19$ & 5 & 119 & 1 & $77.49 / 14$ & 5.0 & $36.8 / 12$ & 57.8 & 33.2 & 9.3 & 7.7 & 11.0 & 70 \\
\hline Switzerland & 17.8 & $0.944 / 2$ & $68.4 / 1$ & 14 & 65 & 2 & $87.42 / 1$ & 5.8 & $34.3 / 24$ & 25.3 & 31.7 & 4.3 & 5.1 & 19.4 & 77 \\
\hline Australia & 8.1 & $0.939 / 3$ & $51.98 / 20$ & 31 & 146 & 8 & $74.12 / 21$ & 9.3 & $21.2 / 105$ & 9.2 & 16.2 & 15.4 & 5.2 & 8.0 & 52 \\
\hline South Korea & 18.5 & $0.903 / 22$ & $56.63 / 12$ & 19 & 142 & 11 & $62.3 / 60$ & 5.7 & $24.8 / 80$ & 2.7 & 63.4 & 11.6 & 5.1 & 6.3 & 26 \\
\hline Kazakhstan & 9.7 & $0.800 / 58$ & $31.42 / 74$ & 43 & 138 & 40 & $54.56 / 101$ & 5.6 & $19.1 / 114$ & 1.6 & 1.2 & 14.4 & 3.0 & 5.3 & 51 \\
\hline U.K. & 4.3 & $0.922 / 14$ & $60.13 / 4$ & 12 & 93 & 65 & $79.89 / 6$ & 4.9 & $31.9 / 34$ & 8.7 & 13.0 & 6.5 & 5.6 & 14.1 & 63 \\
\hline Sweden & 19.0 & $0.933 / 7$ & $63.08 / 3$ & 6 & 115 & 4 & $80.51 / 5$ & 7.3 & $28.0 / 61$ & 53.2 & 68.9 & 4.5 & 7.7 & 9.0 & 68 \\
\hline Netherlands & 15.1 & $0.931 / 10$ & $63.32 / 2$ & 3 & 132 & 28 & $75.46 / 18$ & 5.3 & $35.3 / 18$ & 5.9 & 11.2 & 9.9 & 5.5 & 11.1 & 64 \\
\hline U.S.A & 7.4 & $0.924 / 13$ & $59.81 / 6$ & 47 & 140 & 87 & $71.19 / 27$ & 8.2 & $20.7 / 108$ & 8.7 & 33.9 & 16.5 & 5.0 & 7.8 & 47 \\
\hline Luxemburg & 20.9 & $0.904 / 21$ & $54.53 / 15$ & 49 & 141 & 6 & $79.12 / 7$ & 15.8 & $13.2 / 139$ & 9.0 & 33.5 & 17.4 & 4.0 & 14.3 & 78 \\
\hline France & 7.4 & $0.901 / 24$ & $54.36 / 16$ & 17 & 110 & 67 & $83.95 / 2$ & 5.1 & $30.4 / 44$ & 13.5 & 31.0 & 4.6 & 5.5 & 10.3 & 54 \\
\hline Denmark & 18.5 & $0.929 / 11$ & $58.39 / 8$ & 9 & 97 & 7 & $81.6 / 3$ & 5.5 & $32.7 / 32$ & 33.2 & 14.6 & 5.9 & 7.6 & 16.3 & 70 \\
\hline Russia & 9.0 & $0.816 / 49$ & $37.9 / 46$ & 64 & 144 & 37 & $63.79 / 52$ & 5.7 & $18.7 / 116$ & 3.3 & 49.8 & 11.9 & 3.8 & 5.2 & 35 \\
\hline China & 22.9 & $0.752 / 86$ & $53.06 / 17$ & 85 & 116 & 38 & $50.74 / 120$ & 3.4 & $25.7 / 72$ & 12.4 & 22.2 & 7.5 & - & 5.7 & 68 \\
\hline Canada & 6.0 & $0.926 / 12$ & $52.98 / 18$ & 21 & 147 & 75 & $72.18 / 25$ & 8.2 & $23.9 / 85$ & 22.0 & 38.2 & 15.1 & - & 5.7 & 65 \\
\hline Belarus & 19.3 & $0.808 / 53$ & $29.35 / 86$ & 34 & 125 & 89 & $64.98 / 44$ & 5.1 & $21.7 / 102$ & 6.8 & 42.5 & 6.7 & 5.0 & 6.1 & 51 \\
\hline India & 18.7 & $0.640 / 130$ & $35.18 / 57$ & 87 & 72 & 74 & $30.57 / 177$ & 1.2 & $29.2 / 50$ & 36.0 & 23.8 & 1.7 & 3.8 & 8.4 & 77 \\
\hline Japan & 6.8 & $0.909 / 19$ & $54.95 / 13$ & 15 & 120 & 99 & $74.69 / 20$ & 5.0 & $28.3 / 58$ & 6.3 & 68.5 & 9.5 & 3.6 & 11.0 & 54 \\
\hline
\end{tabular}

Notes: Data refer to the most recent year available during the period specified.

Sources: Human Development Indices and Indicators (2018), United Nations Development Program, New York, www.undp.org;World Development Indicators 2017,World Bank, 2017, Washington, DC: World Bank,

https://openknowledge.worldbank.org/handle/10986/26447. 
World experience shows that countries with large depleted natural capital can compensate for such depletion by increasing savings, increasing spending on health and education, etc. Examples of such countries are Norway, Canada, the United Kingdom, which have positive values of adjusted net savings (see Table 2). Particularly impressive is the example of Norway, which has a high-adjusted net savings index of 20.6, ranks first in the world in the human development index and at the same time actively uses its energy natural capital. Belarus (19.3\%) and Sweden (19\%) have a high positive index. Among the BRICS countries, China and India are the undisputed leaders: the index value is 22.9 and 18.7, respectively. Indicator systems often contain specific indicators of sustainable development presented in the Table 2. Kazakhstan has a very low proportion of forest areas in the total area of the country (1.2\%). Leaders in this area are Sweden (68.9\%), Japan (68.5\%) and South Korea (63.4\%).

The indicator systems necessarily contain indicators related to the energy sector and greenhouse gas emissions. Here, first of all, it is necessary to highlight the widely used in the World Energy Efficiency Indicator (GDP per unit of energy consumed) or its reverse indicator - energy intensity. In the CIS countries, energy efficiency is low, and it is 2 4 times less than in developed countries. Greenhouse Gas Emissions per capita are high in Russia and Kazakhstan, or $12 \sim 14$ tons. However, this figure is significantly inferior to the US and Canada, respectively, 16.5 and 15.1 tons per capita in these countries. In other CIS countries, this figure is 2-3 times lower. In comparison with the world average, the share of renewable energy sources (wind, solar, hydropower, etc.) in the CIS countries is rather low. Here the leaders are Norway and Sweden with a strong potential for hydropower.

The indicators of sustainable development obtained on the basis of sociological research are quite new for the world. Typical issues in this area include "satisfaction with environmental actions" on the part of the population. In Kazakhstan, satisfaction with environmental actions is at an average level (51\% of respondents). Among the CIS countries, low satisfaction with environmental protection actions in Russia (35\%). South Korea also shows low satisfaction (26\% of respondents).

The Adjusted Net Savings Index of the World Bank appears to be the most developed in theoretical terms, with a good statistical base and calculation capacity at the country and regional levels. From the perspective of sustainable development, it is essential to correct the traditional gross savings ratio: the depletion of natural capital (energy and mineral resources, as well as the balance of forest resources) and damage from environmental pollution, including human health (CO2 and particulate matter emissions), are deducted. The "anti-resource" orientation of the adjusted net savings index is obvious: the exploitation of natural resources worsens this indicator. An important advantage of adjusted net savings as an aggregate indicator of sustainable development is its annual calculation for all countries of the world and publication in the World Bank directories of "World Development Indicators". This indicator is already being used by some countries as an official indicator at the macro level. In Kazakhstan, in 2016, the true savings index was negative (-2.3\% of GNI), largely due to the depletion of natural resources.

Calculations published by the World Bank on the basis of the adjusted net savings methodology for all countries showed a significant discrepancy between traditional economic and environmentally adjusted indicators. In Kazakhstan, with formal economic growth, natural capital is being "eaten up" and nature is being degraded, and environmental correction leads to a significant reduction in traditional economic indicators up to negative values of their growth. The comparison of adjusted net savings of Kazakhstan and individual countries is also significant. In developed countries, this figure is 20.6 per cent. World experience shows that countries with large depleted natural capital can compensate for such depletion by increasing savings, increasing spending on education, etc. Norway, Canada, the United States, and the United Kingdom have positive values of adjusted net savings.

Of course, the adjusted net savings index has a number of disadvantages: it does not take into account some important externalities for both positive and negative (damage from land degradation, benefits from ecosystem services, etc.). Nevertheless, this index is important because it tries to give an aggregate assessment of sustainable development, showing the need to compensate for the depletion of natural capital through increased investment in human and physical capital. In practical terms, the index shows the feasibility of creating special funds such as the Fund of Future Generations, which are available in Norway, the United States, and some of oil-producing countries. Such funds are formed at the expense of fixed contributions from the production of dwindling fuel and energy resources to ensure the future development of the country.

Another integral indicator - the Human Development Index (HDI) - has received wide official recognition in the world. Today in Kazakhstan there are many different external and internal problems. The status of an energy-producing country, which previously contributed to economic growth, is now a major challenge. Kazakhstan's economy is heavily dependent on energy exports. In the last decade, the main motive of all transformations and reforms in various spheres of society is the rejection of the so-called "oil needle" and the transition to innovative economic development, in other words, the transition to a "green economy". 
One of the key factors of the innovative economic model is the human capital, which is the driving force of intensive and at the same time, sustainable economic growth, it includes not just the labor force, but also the system of knowledge accumulation, information support of professional activities, as well as the quality of life in the work of each person. The Human Development Index is valuable, at the moment, in connection with the global need for innovation. The higher the level of human development in a country is, the greater the potential for innovation. The economy based on innovations is focused on creation and introduction of essentially new samples of production, new or improved technological processes. Such an economy requires from people, labor collectives, social communities new competencies, new professional and social qualities, properties of human potential, higher all-round human development. It can be noted that the development and improvement of human potential, the quality of life of the population can be achieved only if the transition to a more active introduction of innovations, scientific achievements, the use of new energy and resource-saving technologies, updating the technological base of the entire economy. The problem of formation of human potential susceptible to new developments, innovations, ready for active inclusion in scientific and production processes in the conditions of rapidly changing technologies comes to the fore in the innovative economy. Despite the improvement of Kazakhstan's position in the Human Development Index in 2017 by 2 points compared to 2016, this is a fairly low figure. For clarity, Table 2 presents the results of the top three countries in the world in this ranking.

Global Innovation Index is an annual study conducted by a consortium of Cornell University (USA), the School of Business (France) and the World Intellectual Property Organization(WIPO). By ranking analyzes the growing share of innovations that are created through global innovation networks, which serve as proof that in the face of growing crossborder exchange of knowledge and talents in the broadest possible application of the results of global innovation. There is ample opportunity to deepen cooperation in private and public R\&D to enhance future economic growth. National innovation policies should be more directly aimed at promoting international cooperation and cross-border dissemination of knowledge. The new international governance structures should also seek to increase technology transfer and diffusion to developing countries.

In some cases, low indicators of the environmental component of integrated indices lower the position of Kazakhstan in a particular rating. For example, in the Global Innovation Index (total of 74) for sub-index of "environmental sustainability" Kazakhstan occupied the 107th place in 2018 that, in general, worsened the country's place in the final index. This sub-index measures GDP per unit of energy produced, the Environmental Performance Index and the number of ISO 14001 environmental management certificates issued. At the same time, the place of our country was much higher in most profile indicators (for example, Business environment, Research andDevelopment (R\&D), Information \&Communication Technologies (ICTs), Investment, Knowledge Workers, government's online service and others). The GII Indicators are grouped into innovation inputs and outputs. Kazakhstan to 2018 is a 55 place for innovation inputs, 91 for innovation outputs and 111 forefficiency. If we compare Kazakhstan's performance with other countries, Kazakhstan is ranked 19th among the 34 upper-middle-income countries in the GII 2018, 3rd among the 9 countries in Central and Southern Asia. South Korea in this ranking occupies a fairly high position - 12th place (2018), but in the Global Innovation Index (Bloomberg), South Korea has been leading for several years. This is a vivid example of how the emphasis on different indicators affects the overall ranking of the country. Innovation is not the only way to raise the country's economy, but if the country is doing well with innovation, then the innovation economy is becoming more intensive.

Attempts to calculate integrated indicators of sustainable development, based primarily on environmental parameters, are being made quite actively in the world. Here it should be noted constructive index The Ecological Footprint, which is calculated and published in the Global Report of the World Wildlife Fund. The quantitative indicators of this index by country are shown in Table 2 . The ecological footprint reflects an assessment of the area of bio-productive land on the planet and the measurement of human needs for these bio-productive lands. The Ecological Footprint is expressed in global hectares (per capita) and shows the number of conditional hectares of territory necessary to ensure human life with the current level of consumption and disposal of waste. Calculations of Ecological Footprint show critical for the biosphere "instability" of human development and the global economy - now this index exceeds the bio-capacity of the planet by more than 50\%. Since 1961, the Ecological Footprint has steadily increased and in the mid-1970s exceeded the assimilation capacity of the biosphere. During this period, the biopotential in the world has more than halved. Now humanity uses 1.5 planets to support its activities.

Luxembourg (15.8 ha), Australia (9.3 ha) and the United States ( 8 ha) have a particularly significant impact on the biosphere. In most European countries, the Ecological Footprint is in the range from 5 to 7 hectares. However, it should be noted that the index of the CIS countries over the world (3.3 hectares) - 1.4 1.7 times, which is primarily due to the significant emission of greenhouse gases by these countries. 
Sustainable Society Index 2016 clearly demonstrates the low level of environmental well-being of Kazakhstan (138 position), while the indicators of social (43 position) and economic (40 position) well-being are satisfactory.

Environmental Performance Index is one of the most reputable in the world. It is used by the UN to assess progress towards the 2030 Sustainable Development Goals and the implementation of the Paris climate agreement. The index is calculated on the basis of indicators belonging to nine problem categories (impact on health, air quality, water resources, biodiversity and habitats, climate and energy, etc.). The index assesses the state of ecosystems and the quality of the environment. In 2014 and 2016, the rating was based on 20 indicators, while maintaining the same problem categories. a number of new indicators were used to calculate the index, as a result of which the weight of the categories changed. In 2018, the index is calculated on the basis of 24 indicators in 10 categories with a focus on indicators such as climate and energy, biodiversity and habitats, air quality. Changes in the indicators on which the rating is calculated lead to the fact that it is not possible to compare the results of the country in dynamics. However, 101 place of Kazakhstan in 2018 among 180 countries indicates environmental vulnerability.

The world's largest database of cities and countries,Numbeo published statistics on the level of pollution of the environment around the world (Pollution Index for Country) - reverse ranking. Experts estimate how much each country harms itself, as well as how much its ecology spoils the environment of the entire planet. The first indicator is based on data from the World Health Organization and feedback from people who have visited the country. The second is an index calculated according to a complex scheme, which includes data not only from the WHO, but also from a huge number of environmental organizations. It is worth noting that the concept of "environmental pollution" includes air, water and soil pollution. Kazakhstan takes the 25th place out of 106 countries in this ranking of 2019, and South Korea is 64th place. In the international index of happy planet (Happy Planet Index 2016) Kazakhstan occupies 114 ranks from 140 countries. This index consists of three indicators such as life satisfaction, life expectancy and ecological footprint.

Many countries have developed their systems or integrated indicators of sustainable development. Kazakhstan also attempted to develop an index. Based on the OECD methodology, the integrated indicator "Better Life Index", Kazakhstan in 2017 calculated the quality of life index (HIC). ICW is a system of indicators on 11 aspects of wellbeing chosen by the OECD to characterize the country's development process. The OECD considers the development process not only as an improvement of material or economic well-being, but also as an expansion of the "opportunities" of a person, that is, the opportunities to live a long and healthy life, to do more useful things. In recent decades, Kazakhstan has achieved considerable success in improving the quality of life of the population. At the same time, according to the indicators included in the ICW, calculated according to the OECD methodology, Kazakhstan has not yet reached the average values in comparison with the OECD countries.

Table 3. Quality of Life Index in Kazakhstan in 2017

\begin{tabular}{|c|c|}
\hline Criteria & Result \\
\hline Housing & $\begin{array}{l}\text { In } 2017 \text {, the housing conditions of the population in the Republic of Kazakhstan have not } \\
\text { changed. On average, there were } 0.8 \text { rooms per person, which is less than the OECD } \\
\text { average of } 1.8 \text { rooms. }\end{array}$ \\
\hline Income & $\begin{array}{l}\text { The average adjusted net income of the household after taxes was us } \$ 9,517 \text { per year } \\
\text { (PPP), and the average for OECD countries was us } \$ 30,563 \text { per year. }\end{array}$ \\
\hline Work & $\begin{array}{l}\text { In terms of employment, more than } 74 \% \text { of the population aged } 15 \sim 64 \text { in Kazakhstan had } \\
\text { paid employment, which was significantly higher than the average employment rate in } \\
\text { OECD countries }(67 \%) \text {. About } 81 \text { per cent of men had paid jobs and } 74 \text { per cent of } \\
\text { women. At the same time, only a small share (1.5\%) of workers in Kazakhstan had an } \\
\text { increased working day compared to } 12.6 \% \text { - on average in OECD countries. }\end{array}$ \\
\hline Education & $\begin{array}{l}84.5 \% \text { of the adult population of Kazakhstan aged } 25 \sim 64 \text { has complete secondary } \\
\text { education (according to the } 2009 \text { census), which is significantly higher than the OECD } \\
\text { average ( } 74 \% \text { ). As for the quality of education, according to the latest data of the OECD } \\
\text { International Program for the assessment of educational achievements of students (PISA, } \\
2015 \text { ), the average student in Kazakhstan is gaining } 448 \text { points in the quality of reading, } \\
\text { knowledge in mathematics and science, which is slightly below the OECD average ( } 486 \\
\text { points). }\end{array}$ \\
\hline Health & $\begin{array}{l}\text { In terms of population health, life expectancy at birth in Kazakhstan in } 2017 \text { was } 73 \\
\text { years, which is } 7.2 \text { years less than the OECD average ( } 80.1 \text { years). Life expectancy for } \\
\text { women was } 76.9 \text { years and for men } 68.7 \text { years. }\end{array}$ \\
\hline Ecology & In Kazakhstan, PM 2.5 content of small solid particles that can enter even the deepest \\
\hline
\end{tabular}




\begin{tabular}{|l|l|}
\hline & $\begin{array}{l}\text { part of the lungs (PM 2.5 index) is } 20 \text { micrograms per cubic meter, which is higher than } \\
\text { the OECD average (14 micrograms per cubic meter). 85\% of the population is satisfied } \\
\text { with the quality of water used in Kazakhstan, which is higher than the OECD average } \\
(81 \%) .\end{array}$ \\
\hline Society & $\begin{array}{l}\text { As for the social sphere, Kazakhstan is characterized by a moderately high sense of } \\
\text { involvement in society and a moderately high level of people's participation in public } \\
\text { life: } 91 \% \text { of the population of Kazakhstan are sure that they have someone to rely on in } \\
\text { difficult times, this is significantly more than the OECD average (89\%). }\end{array}$ \\
\hline Civil Rights & $\begin{array}{l}\text { Voter turnout (an indicator of public trust in the government and citizens' participation in } \\
\text { political life) during the last elections to the maslikhats was 72\%, which is higher than } \\
\text { the OECD average (69\%). }\end{array}$ \\
\hline Life Satisfaction & $\begin{array}{l}\text { In general, Kazakhstanis are no less satisfied with their lives than the average resident of } \\
\text { the OECD countries: in Kazakhstan, 72\% of respondents believe that during the day they } \\
\text { experience more positive emotions (a sense of calm and confidence, pride in the } \\
\text { achievements, joy, etc.) than negative ones (pain, anxiety, sadness, boredom, etc.). This } \\
\text { is above the OECD average (65\%). }\end{array}$ \\
\hline Security & $\begin{array}{l}\text { According to the latest data, more than 91\% of the population of Kazakhstan noted that } \\
\text { they feel safe walking the streets at night, which is much higher than in the OECD } \\
\text { countries (69\%). }\end{array}$ \\
\hline Work/Leisure & $\begin{array}{l}\text { In } 2017, \text { the number of employees working } 50 \text { hours or more per week in Kazakhstan } \\
\text { was } 1.5 \%, \text { when } 13 \% \text { of employees work overtime in OECD countries. }\end{array}$ \\
\hline
\end{tabular}

Source: www.stat.gov.kz.

The analysis of Kazakhstan's place in the international environmental ratings revealed a number of factors influencing its position and, at the same time, not always providing an objective description of the environmental situation. First of all, it is sometimes a very complex and not always a transparent method of calculating some indices. The use of complex formulas leads to the fact that the country's place in the final ranking differs significantly from its position determined by individual indicators included in it. This, to some extent, "hides" real environmental problems or, on the contrary, does not allow to record, including at the international level, the progress made in certain areas.

Kazakhstan's place in the global rankings and its strengths and weaknesses of environmental development will reflect the state of environmental capacity, environmental management and policy of our country in the field of environment. Cross-country comparisons show that Kazakhstan lags behind the leading countries in many areas of environmental development.

Table 4. Strength and Weakness of Kazakhstan based onSustainable Development Indicators

\begin{tabular}{|l|l|}
\hline \multicolumn{1}{|c|}{ Weakness } & \multicolumn{1}{|c|}{ Strength } \\
\hline 1.Ecological state of the country: high rate of & 1. Significant improvement in the human development \\
Ecological Footprint and high level of carbon & index: Kazakhstan is among the countries with very high \\
dioxide emissions. & human development. \\
2. Low energy efficiency. & 2. Creating a good business environment: the 34th place on \\
3. Insufficient share of renewable energies. & this sub-index GII. \\
4. Insufficient level of innovation. & 3.Employment. \\
5.Low education costs. & 4.Moderately high level of public participation. \\
\hline
\end{tabular}

Thus, the essence of the economy emerges from the above sustainable development. The economics of sustainable development isa modern ecological and economic system, emerging in the global information space, as information and knowledge areas a direct productive force that determines the ways and rates of innovation economy, the nature of technical, organizational and structural changes, and consequently, significant progress in sustainable development.

\section{Conclusion}

The study of the existing theoretical and methodological approaches to the formation of Indicators of Sustainable Developmentin Kazakhstan as well as modern trends in the development of such indicators is allowed to draw the following conclusions:

1. Sustainable development can be broadly defined as development that ensures economic efficiency, social justice and environmental security for present and future generations. 
2. Indicators of sustainable development are indicators that characterize the achieved level of social, economic and environmental sustainability of socio-economic systems in the dynamics and the degree of their adaptability to the influence of factors of internal and external environment. Such indicators serve as a basis for monitoring the sustainable development of economic systems.

3. The development of indicators of sustainable development is an important stage in the implementation of the sustainable development strategy.

4. There are the following main methodological approaches to assessing and monitoring the level of sustainable development of economic systems: the use of an integrated indicator of sustainable development; the development of a system of indicators of sustainable development; the use of special indicators; sociological survey.

5. Indicator systems are different types of models: "topic and sub-topic indicators"," pressure - state - reaction indicator","aspect indicator","subsystem indicator", etc.

6. Modern trends in the development of indicators of sustainable development of economic systems are included: the use, along with quantitative qualitative indicators obtained on the basis of the survey, including through the Internet; the lack of many methods of clear allocation of groups of social, economic, environmental and other indicators; the formation of information systems, including using the Internet, which makes the relevant information transparent and accessible to large groups of specialists and the population on a global scale.

7. Sustainable development indicator systems perform the following functions: (i) assess the achieved level of sustainable development, (ii) allow the use of statistical reporting data available to researchers, (iii) unify the evaluation system through the use of a limited number of "selected" indicators, (iv) allow monitoring of sustainable development in time and by levels of economic systems: global, interethnic, national, regional (territorial), local (local), large economic system (subsystem), industry, economic entity (enterprise), (v) enable the creation of databases and information systems for sustainable development, (vi) allow to provide availability of the specified information systems for wide audience by means of the internet, (vii) provide an opportunity to identify positive and negative processes taking place in the economic system, (viii) contribute to the identification of the causes of instability of the economic system, (ix) help researchers find tools and mechanisms that increase resilience, (x) facilitate the implementation of the sustainable development strategy, (xi) enable the development and introduction of new indicators as the economic system develops, and (xii) allow you to "reserve" for the future important indicators, the calculation method of which has not been developed to date.

8. The development of indicators of sustainable development of economic systems is based on the following basic principles: (i) mapping of strategic goals and objectives of sustainable development, (ii) hierarchy, when, for example, each section in the indicator system corresponds to certain subsections, and each subsection has a group of indicators, (iii) compliance with the system of collection and processing of information used in the state statistical reporting, (iv) flexibility, i.e., the ability to develop and introduce new indicators, (v) limited number of indicators reflecting the most significant trends towards sustainable development, (vi) universality, i.e., possibility to use in various program documents, (vii) integrated approach, i.e., reflection of social, economic and environmental aspects of sustainable development.

9. The main criteria that can be used as a basis for the development of indicators of sustainable development of economic systems are economic efficiency, social equality and environmental safety for existing and future generations ${ }^{15}$.

10. Far from satisfactory overall situation in the international environmental arena of Kazakhstan makes it necessary to take urgent measures on many aspects of environmentally sustainable development. Kazakhstan has a huge, virtually unused resource of "greening" the economy and improving energy efficiency, which in case of progress can create good prospects for improving the environment and environmental development. The importance of this direction is evidenced by the priorities of Kazakhstan's environmental policy, set out in the documents of the Concept for the Transition of the Republic of Kazakhstan to the "green economy" and the laws of the Republic of Kazakhstan "On Energy Saving and Energy Efficiency" ${ }^{\text {" }}$. Environmental parameters are becoming an increasingly important component of the positioning of a country on the world stage, the competitiveness of regions, cities and companies. This has become a clear global trend, judging by the rapid surge of the "industry" of international and domestic environmental ratings over the past 10 15 years. The use of quantitative indicators and indexes for assessing the effectiveness of environmental policies and sustainable development will continue to develop rapidly,

\footnotetext{
${ }^{15}$ Lagodich, L. V. (2014),"Measurement of sustainable development: problems of theory, methodology, practice”, Economics and Management, Vol. 40, No. 4, pp. 4-7(in Russian).

${ }^{16}$ The concept of transition of the Republic of Kazakhstan to "green economy" approved by the decree of the President of the Republic of Kazakhstan dated May 30, 2013, No. 577 (in Russian).

${ }^{17}$ On Energy Saving and Energy Efficiency Law of the Republic of Kazakhstan, No. 541-IV of 13 January 2012 (in Russian).
} 
including in connection with new initiatives - the implementation of the Agenda for Sustainable Development the UN for the period up to 2030 and the Paris Agreement of 2015, the assessment of quantifiable goals and objectives of the countries and regions in the framework of these agreements will require further improvements in technologies for collecting, processing, analysis and dissemination of environmental data. At the same time, the ratings will retain their importance as one of the analytical tools that provide visual and independent information for decision-making, including in the environmental sphere.

\section{References}

Alekseeva, N.N., M.A. Arshinova andA.I. Bancheva (2018), "Russia's position in international environmental ratings",RUDN Journal of Ecology and Life Safety, 26 (1), pp. 134-152(doi: 10.22363/2313-2310-2018-26-1134-152).

Bobylev, S. (2017),Sustainable Development Indicator, https://postnauka.ru/video/80745 (in Russian).

Bobylev, S.N. (2007),Indicators of sustainable development: regional dimension. Handbook of regional environmental policy, Moscow: Acropolis, CEPR(in Russian).

Böringer, C. and P.Jochem(2007),"Measuring the Immeasurable: A Survey of Sustainability Indices", ZEW, Discussion Paper, No. 06-073.

EEA Technical Report (2014), “Digest of EEA indicators 2014”, European Environment Agency, 2014, No. 8.

Global Footprint Network(2016), National Footprint Accounts, 2016 Edition. https://www.footprintnetwork.org

Sustainable Society Index (2016), Sustainable Society Foundation, http://www.ssfindex.com

Hsu, A. et al. (2016),The 2016 Environmental Performance Index, New Haven, CT: Yale University,www.epi.yale.edu.

Human Development Indices and Indicators (2018), United Nations Development Program, New York, www.undp.org

Indicators of Sustainable Development of Russia: Ecological and Economic Aspects (2001), by S. N. Bobylev, P. A. Makeenko, Moscow(in Russian).

Lagodich, L. V. (2014),"Measurement of sustainable development: problems of theory, methodology, and practice", Economics and management, No. 4 (40)(in Russian).

Numbeo,Pollution Index for Country 2019, URL: https://www.numbeo.com /pollution/rankings_by_country.

On Energy Saving and Energy Efficiency. Law of the Republic of Kazakhstan, No. 541-IV of 13 January 2012 (in Russian).

Stiglitz, J.E., A.Sen andJ.P. Fitoussi (2010),Mis-measuring Our Lives: Why GDP Doesnot Add Up, The New Press.

The Concept of Transition of the Republic of Kazakhstan to "green economy" approved by the decree of the President of the Republic of Kazakhstan dated May 30, 2013, No. 577 (in Russian).

The Global Innovation Index 2018: Energizing the World with Innovation (2018), Cornell University, INSEAD, and the World Intellectual Property Organization, https://www.wipo.int/publications/ru/details.jsp?id=4330.

The Little Green Data Book (2017), Washington, DC: World Bank (doi: 10.1596/978-1-4648-09286,http://documents.worldbank.org). 